\title{
Formacja katolików świeckich do modlitwy Liturgią Godzin
}

\section{THE FORMATION OF LAY CATHOLICS TO PRAYER THROUGH THE LITURGY OF THE HOURS}

The Liturgy of the Hours, in accord with the teaching of the Church, is the prayer of all of the People of God. Everybody participates in accordance with their position in the Church: presbyters as well as all the lay faithful, to the extent they are able. This liturgical prayer of the Church can become the beginning of personal prayer if first the pastors are convinced of the significance of the Liturgy of the Hours in the life of the Church, the parish and in the internal life of the individual lay persons. There is a necessity for the formation of laity in this regard. There is also a need for adequate formation in seminaries as it relates to this matter. It is of great importance to celebrate the patrons of archdioceses, dioceses and parishes together with the Liturgy of the Hours with participation of laity. It is necessary to properly conduct biblical-liturgical catechesis for the lay people. It is of importance to underline the Liturgy of the Hours in the community, the family, the individual, groups and organizations.

Key words: The Liturgy of the Hours, prayer, celebration, formation, the song of praise, laity. 


\section{Wprowadzenie}

Katechizm Kościoła Katolickiego wyraźnie stwierdza, że Liturgia Godzin powinna stać się modlitwą całego Ludu Bożego. Każdy bierze w niej udział - zgodnie z miejscem w Kościele: prezbiterzy, jako pełniący posługę duszpasterską, zakonnicy i zakonnice przez charyzmat swego życia konsekrowanego, zaś wszyscy wierni według możliwości i potrzeb ${ }^{1}$. Liturgia Godzin domaga się - na zasadzie komplementarności - różnorakich form pobożności Kościoła, szczególnie adoracji i kultu Najświętszego Sakramentu². Dlatego, niezmiernie ważna jest odpowiednia formacja katolików świeckich do Liturgii Godzin. Celem niniejszego artykułu jest ukazanie wartości modlenia się Liturgią Godzin oraz potrzeby odpowiedniej formacji świeckich do tej formy modlitwy.

\section{Znaczenie i godność Liturgii Godzin} w życiu Ludu Bożego

Ośrodkiem, źródłem i szczytem całego życia Kościoła jest Eucharystia $^{3}$. W niej to w różny sposób łączą się wszelkie działania Kościoła, a szczególnie trzy elementy liturgii: celebracja Słowa Bożego, Liturgia Godzin oraz rok liturgiczny.

Dzięki Boskiemu Oficjum - Liturgii Godzin - realizuje się uświęcenie czasu, ludzkiej działalności, kultury, historii, a przede wszystkim nieustanne uwielbienie Boga. Ten hymn uwielbienia, wniesiony w rzeczywistość ludzką przez Wcielony Logos, wyraża chwałę Boga i kieruje ją ku Przedwiecznemu Ojcu. Czyni to razem ze swoim Ciałem - Kościołem ${ }^{4}$.

Sobór Watykański II w Konstytucji o liturgii naucza:

Gdy kapłani oraz inne do tego przez Kościół wyznaczone osoby, lub też modlący się wspólnie z kapłanem wierni, według zatwierdzonej formy, wykonują tę przedziwną pieśń chwały, wówczas jest to prawdziwie głos Oblubienicy, przemawiającej do Oblubieńca. Co więcej, jest to modlitwa Chrystusa i Jego ciała zwrócona do Ojca ${ }^{5}$.

$1 \quad$ Catechismus Catholicae Ecclesiae, Città del Vaticano 1994; tekst polski: Katechizm Kościoła Katolickiego, Poznań 1994, nr 1175.

2 Ibidem, nr 1178.

3 Konstytucja dogmatyczna o Kościele Lumen gentium, nr 11 (odtąd skrót KK).

4 Konstytucja o liturgii świętej Sacrosanctum Concilium, nr 83 (odtąd skrót KL).

$5 \mathrm{KL}, \mathrm{nr} 84$. 
Każdy ochrzczony, który odmawia tę modlitwę, wypełnia zadanie Kościoła, uczestnicząc w najwyższym zaszczycie Oblubienicy Chrystusa, ponieważ oddawszy Bogu chwałę, staje przed tronem Bożym w imieniu Matki Kościoła ${ }^{6}$. Celem Liturgii Godzin jest uświęcenie dnia $^{7}$. Każdy, kto tę modlitwę odmawia - czy to we wspólnocie, czy prywatnie - uwielbia Boga i uświęca się. Sobór Watykański II zachęca do tego, by nie tylko duchowni odmawiali te modlitwę, ale także świeccy - czy to z prezbiterami, czy na różnego rodzaju spotkaniach lub indywidualnie ${ }^{8}$.

Liturgia Godzin bierze swe źródło ze zwyczajów modlitewnych narodu żydowskiego. Izraelici w określonych porach dnia i nocy wznosili modlitwę do Boga ${ }^{9}$. Omawiana forma modlitwy rozwijała się stopniowo, etapami. Przede wszystkim, była modlitwą Kościoła lokalnego, sprawowaną pod przewodnictwem kapłana w określonych godzinach i miejscach na to przeznaczonych. Paweł VI w konstytucji apostolskiej, wprowadzającej w życie Liturgię Godzin (1970), nazwał Liturgy ją pieśnią chwały - Laudis canticum ${ }^{10}$.

Rola Soboru Watykańskiego II w zakresie odnowy Liturgii Godzin nie polega tylko na zmianach strukturalnych modlitwy Kościoła, lecz na uwypukleniu jej niezwykłej głębi teologicznej. Ona właśnie leży u podstaw nowej wizji liturgia horarum i jej sprawowania. Biblia i historia stanowi fundament teologii Liturgii Godzin. Jest ona dialogiem Boga z ludźmi, a więc z Kościołem, przez co funkcjonuje w związku z Eucharystią i działalnością pasterską ${ }^{11}$. Kiedy Kościół sprawuje Liturgię Godzin, chwali Boga Ojca, potwierdza swoją tożsamość, jako wspólnoty powołanej przez Boga w Jezusie Chrystusie - Ludu Bożego. Dzieje się to w konkretnej lokalnej wspólnocie Kościoła ${ }^{12}$. Sprawowanie Liturgii Godzin nie jest tylko manifestacją Ludu Bożego, ale potwierdza posłannictwo Kościoła w sensie wykonywania zadania, do którego został powołany - wykonuje królewskie kapłaństwo, gromadzi się przed Bogiem w Duchu Świętym, by stać się przez celebrację Liturgii Godzin „uczestnikiem Boskiej natury” (1 P 1,4).

6 Por. KL, nr 85.

7 Por. Ibidem, nr 88.

8 Por. Ibidem, nr 99.

$9 \quad$ W. Głowa, Modlitwa liturgiczna. Liturgia Godzin, Przemyśl 1996, s. 20-21.

10 Paweł VI, Konstytucja Apostolska, wprowadzająca w życie Liturgię Godzin, uchwaloną dekretem Drugiego Soboru Watykańskiego, [w:] Ogólne wprowadzenie do Liturgii Godzin, Poznań 1992, s. 12-18 (odtąd skrót OWLG).

11 OWLG, nr 14.

$12 \mathrm{KL}, \mathrm{nr} 14$. 


\section{Liturgia Godzin sprawowaniem kapłaństwa wspólnego}

W Liturgii Godzin Kościół spełnia kapłański urząd Chrystusa, składając Bogu „nieustannie” ofiarę czci, czyli owoc warg, które uwielbiają Boga i wymieniają Jego Imię ${ }^{13}$. Kościół nie jest pozbawiony łączności wzajemnej. Nasza modlitwa ma wymiar wspólnotowy - to jest istotna cecha Kościoła. Źródłem jedności Kościoła jest Słowo Boże, braterska wspólnota, modlitwa, Eucharystia. Modląc się, wspólnota chrześcijańska nie tylko sprawuje „pieśń chwały”" użyczając „ust i serca” całemu kosmosowi, który modli się w człowieku i przez człowieka, ale równocześnie „godziny modlitewne” stają się wielką służbą światu, który nie chce, bądź nie potrafi się modlić ${ }^{15}$.

\section{Liturgia Godzin modlitwą uwielbienia Boga przez Kościół}

Konstytucja o liturgii zaznacza, że Liturgia Godzin ,,jest głosem Kościoła czyli całego Mistycznego Ciała, które publicznie wielbi Boga" ${ }^{16}$. Jest to publiczna modlitwa Kościoła ${ }^{17}$. Do modlitwy tej wezwani są wszyscy, nie tylko biskupi, kapłani czy diakoni, lecz cały Lud Boży, ponieważ wszyscy jesteśmy winni Bogu chwałę. Kiedy poszczególne osoby zobowiązane do odmawiania tej liturgii modlą się, jest to zawsze głos Kościoła skierowany do Chrystusa.

Modlitwa Kościoła, spełniona w imię Chrystusa, rozwija historię Zbawienia w świecie, staje się nosicielką tej historii i przyczynia się do realizacji Bożych zamysłów, w konsekwencji przybliżając Królestwo Boże. Zobowiązani do Liturgii Godzin modlą się za „własną owczarnię”" błagając Boga za „cały powierzony sobie lud” "19, za Kościót ${ }^{20}$. Konstytucja o liturgii świętej mówiąc o brewiarzu podkreśla, że wszyscy oddani tej modlitwie wypełniają zadanie Kościoła ${ }^{21}$. Ogólne wprowadzenie do Liturgii Godzin poucza, że „słusznie zalicza się publiczną i wspólną modlitwę Ludu Bożego do głównych powinności

\footnotetext{
13 OWLG, nr 15.

14 OWLG, nr 16.

15 Ibidem, nr. 31, 42, 78.

$16 \quad \mathrm{KL}, \mathrm{nr} 99$.

17 Por. ibidem, nr. 90, 98.

18 OWLG, nr 17.

19 Ibidem, nr 28.

20 Por. KL, nr 26.

21 Ibidem, nr 85.
} 
Kościoła”22. Czytając dalej dowiadujemy się, że w modlitwie tej chodzi „o najbardziej istotną cechę Kościoła. Jest on bowiem wspólnotą i ma to wyrażać także i w modlitwie"23.

\section{Sposoby formacji katolików świeckich do modlitwy Liturgią Godzin}

\section{Rola duszpasterzy w formacji świeckich}

Duszpasterze muszą być głęboko przekonani o sensie odnowy liturgicznej na odcinku modlitwy Kościoła. Ogólne wprowadzenie mówi, że duszpasterze mają zachęcać wiernych do udziału w głównych częściach Liturgii Godzin, zwłaszcza w niedziele i święta oraz przygotowywać ich do tego odpowiednimi pouczeniami. Wierni powinni rozumieć, że Liturgia Godzin jest autentyczną szkołą modlitwy ${ }^{24}$.

Sobór Watykański II przywraca wiernym w całej pełni udział w Liturgii Godzin, głównie dzięki wprowadzeniu języków ojczystych do niej. Wskazując na soteriologiczny i kultyczny charakter liturgii, Sobór pomógł odkryć i zrozumieć Ludowi Bożemu, że liturgia Kościoła, a więc i modlitwa brewiarzowa, jest źródłem odnowy życia chrześcijańskiego i że Lud ten, na mocy królewskiego kapłaństwa, ma prawo i obowiązek w niej uczestniczyć świadomie i „,czynnie”. Już Konstytucja o liturgii dostrzega świeckich katolików, modlących się „wspólnie z kapłanem”25. Ogólne wprowadzenie mówi około 40 razy o udziale świeckich w modlitwie brewiarzowej. Odnowione prawo liturgiczne dotyczące brewiarza, stawia na pierwszym miejscu taki sposób celebracji Liturgii Godzin, w której biorą udział świeccy i zachęca do takiego właśnie wykonywania tej modlitwy ${ }^{26}$. Wielkie zadanie $\mathrm{w}$ tej mierze stoi przed wspólnotami, stowarzyszeniami czy różnorodnymi ruchami kościelnymi. Wielką rolę w tej formacji odgrywa Oaza Nowego Życia II czy III stopnia. Podczas rekolekcji oazowych szczególną uwagę przywiązuje się do formacji, dotyczącej Liturgii Godzin. Moderatorzy

\footnotetext{
22 OWLG, nr 1 .

23 Ibidem, nr 9 .

24 OWLG, nr 23; Słowo Biskupów do kapłanów z okazji wprowadzenia Liturgii Godzin w języku polskim (1982), [w:] Dokumenty Duszpastersko-Liturgiczne Episkopatu Polski 1966-1993, oprac. Cz. Krakowiak, L. Adamowicz, Lublin 1994, s. 265-271.

$25 \mathrm{KL}, \mathrm{nr} .84-100$.

26 OWLG, $\mathrm{nr} 270$.
} 
ruchów winni zachęcać i pomagać w przygotowywaniu pięknej liturgii. Także rodziny powinny włączyć się w czynności liturgiczne, chociażby w organizowanie adoracji przy ołtarzu wystawienia obok Grobu Pańskiego. Triduum Paschalne jest doskonałą okazją do zwrócenia uwagi i włączenie wiernych ze wspólnoty parafialnej w celebrację Liturgii Godzin, zwłaszcza Jutrzni i Godziny Czytań. Praktyka organizowania tzw. ciemnych jutrzni w kościołach parafialnych dla wielu spośród parafian jest okazją do okrycia - czym w ogóle jest - modlitwa brewiarzowa.

\section{Liturgiczna formacja w seminariach duchowych i zakonnych domach studiów}

Liturgia Godzin jest fundamentem formacji seminaryjnej/zakonnej ${ }^{27}$. Dlatego należy podtrzymywać w seminariach zwyczaj wspólnego sprawowania tej modlitwy i to z zastosowaniem śpiewu. Liturgia Godzin ma harmonizować z innymi praktykami pobożności. Jako swoiste minimum, należy wspólnie odprawiać, z zachowaniem odpowiedniej pory dnia, Jutrznię i Nieszpory ${ }^{28}$. Godnym praktykowania jest łączenie tychże godzin z Mszą św. - zwłaszcza w dni świąteczne, w dniu patrona diecezji czy seminarium z racji dni skupienia, rekolekcji.

W myśl dokumentów soborowych i posoborowych Kościoła, we wspólnocie seminaryjnej powinno obchodzić szczególnie uroczyście doroczny cykl tajemnic Chrystusa. Instrukcja o liturgicznej formacji w seminariach przypomina, że „(...) należy zadbać o to, aby dzień Pański oraz główne obchody ku czci Chrystusa, Matki Najświętszej i Świętych odznaczały się charakterem świątecznym i były dniami radości" 29 .

\section{Obchody ku czci patronów metropolii, diecezji, parafii}

Wyjątkową wagę należy przywiązywać do obchodów dni ku czci świętych danej diecezji, metropolii. Należy obchodzić uroczyście rocznicę poświęcenia katedry i rocznicę święceń biskupa diecezjalnego. W tej mierze powinno się wiernych odpowiednio pouczać.

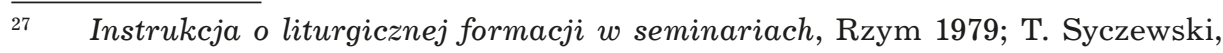
Liturgiczna formacja alumnów $w$ wyższych seminariach duchownych w świetle dokumentów odnowy soborowej, „Studia Teologiczne. Białystok - Drohiczyn Łomża" 10 (1992), s. 98-99.

28 Por. ibidem, nr. 28-30.

29 Por. KL 102-105. 
Dokumenty Synodu Diecezji Drohiczyńskiej przypominają, że Liturgia Godzin jest modlitwą całego Kościoła ${ }^{30}$. Została ułożona w ten sposób, iż mogą ją odmawiać nie tylko duchowni, osoby zakonne, ale przeznaczona jest ona również dla katolików świeckich ${ }^{31}$. Modlitwa ta uświęca człowieka i oddaje cześć Bogu. Dzięki tej modlitwie człowiek nawiązuje dialog ze Stwórcą. Głównym celem tej modlitwy jest uświęcenie poszczególnych godzin dnia i ludzkiej pracy, całej działalności ${ }^{32}$.

Liturgia Godzin przygotowuje prezbiterów do owocnego celebrowania Eucharystii. Ożywia odpowiednie usposobienie, właściwą postawę wiary, nadziei, miłości i pobożności. Wyrabia również ducha ofiary i wyrzeczenia ${ }^{33}$.

Katolicy świeccy uczestniczący w tej modlitwie w jedności serc i głosów, stają się widocznym znakiem Kościoła, sprawującym misterium Chrystusa ${ }^{34}$. Wymaga to ze strony duszpasterzy odpowiedniego przygotowania, właściwej katechezy, która ukazałaby najważniejsze treści teologiczne Liturgii Godzin. Nauczyłaby także - od strony tech- Liturgy nicznej - właściwego posługiwania się tą formą modlitwy. Katecheza taka wprowadziłaby wiernych w sens poszczególnych godzin.

Do tej modlitwy zachęca się samych wiernych świeckich na przykład podczas spotkań rodzinnych ${ }^{35}$. Przez odmówienie przynajmniej części Liturgii Godzin, np. Jutrzni lub Nieszporów gromadzą się jako wspólnota wiary. Ponadto zachęca się wiernych, by i w rodzinie, która jest „domowym sanktuarium Kościoła”, w miarę możliwości odmawiano przynajmniej jakąś część Liturgii Godzin, jednocząc się w ten sposób jeszcze ściślej z całym Kościołem ${ }^{36}$. W rodzinie, jako „domowym Kościele”, jest wiele wspaniałych momentów, w których ta modlitwa mogłaby odnaleźć swoje miejsce: niedziele, uroczystości, rocznice rodzinne, pierwsza Komunia św., sakrament bierzmowania. W ten sposób cała rodzina mogłaby włączyć się w kult liturgiczny ${ }^{37}$.

30 ISynodDiecezji Drohiczyńskiej.Statuty, dokumenty wykonawcze, red.M. Łaziuk, A. Dzięga, Drohiczyn 1997, nr 185.

$31 \quad$ Konstytucja Apostolska wprowadzająca w życie Liturgie Godzin uchwalona dekretem Drugiego Soboru Watykańskiego, [w:] Liturgia Godzin, t. I, Poznań 1982, nr 1; Kodeks Prawa Kanonicznego, kan. 1173 -1174.

32 Konstytucja Apostolska, nr 2.

$33 \quad$ Por. I Synod Diecezji Drohiczyńskiej, nr 185.

$34 \quad$ Ibidem, $\mathrm{nr} 22$.

$35 \mathrm{KL}, \mathrm{nr} 100$.

$36 \quad$ OWLG, nr 27; Dekret o apostolstwie świeckich, $\mathrm{nr} 11$.

37 Ibidem. 
Liturgia Godzin najlepiej przygotowuje kapłanów, a także i katolików świeckich do owocnego sprawowania i przeżywania Eucharystii oraz ożywia odpowiednie usposobienie, postawę głębokiej wiary, nadziei, miłości, pobożności i ducha ofiary. Pierwszy Synod Diecezji Drohiczyńskiej przypomina, aby tam, gdzie jest to możliwe i zasadne, Jutrznia lub Nieszpory były odprawiane w kościele z udziałem katolików świeckich, zwłaszcza członków małych wspólnot np. Oazy, Grupy Synodalne, Akcji Katolickiej, Wspólnot Neokatechumenalnych, Rodzin Nazaretańskich, Sodalicji Mariańskich, Wspólnoty Odnowy w Duchu Świętym, młodzieży itp. Również samych katolików świeckich zachęca się do wspólnej modlitwy Kościoła przez odmówienie przynajmniej którejś z jej części, ilekroć gromadzą się jako wspólnota wiary.

Papież Paweł VI w Konstytucji Apostolskiej, wprowadzającej w życie liturgię godzin uchwaloną Dekretem II Soboru Watykańskiego napisał:

Modlitwa chrześcijańska jest przede wszystkim modlitwą całej społeczności ludzkiej, którą Chrystus łączy z sobą. Mają w niej udział poszczególni jej uczestnicy, a jednocześnie jest ona modlitwą całego Ciała; jest głosem umiłowanej Oblubienicy Chrystusowej, wypowiadającym pragnienia i prośby ludu chrześcijańskiego, a także błagania o zaspokojenie potrzeb wszystkich ludzi. Jedność tej modlitwy płynie z serca Chrystusa. Pragnął bowiem nasz Odkupiciel, by życie, które rozpoczął w swym ziemskim ciele przez modlitwy i ofiarę, przetrwało przez wieki w Jego Ciele Mistycznym, czyli w Kościele ${ }^{38}$.

Liturgia Godzin wyraża najgłębszą istotę życia chrześcijańskiego i dopomaga w jej urzeczywistnieniu, stąd przeznaczona jest dla wszystkich, także i dla tych, którzy nie są zobowiązani prawem do jej celebracji. Ci zaś, którym Kościół nakazał odmawianie liturgii godzin, niech to czynią pobożnie i w całością ją sprawują, pamiętając także w miarę możności zachować zgodność godzin brewiarzowych z godzinami dnia.

\section{Permanentna katecheza biblijno-liturgiczna katolików świeckich}

Zanim wprowadzi się świeckich w Liturgię Godzin, należy nauczyć ich modlić się psalmami, stąd potrzebna jest długofalowa, wieloaspektowa formacja biblijno-liturgiczna. Konieczne jest permanentne wprowadzenie wiernych w Biblię, jak i w modlitwę psalmami ${ }^{39}$. Przykładem takiego wtajemniczenia w modlitwę Liturgią Godzin jest wspomniana już Oaza Nowego Życia. Ona wprowadza uczestników

$38 \quad$ Konstytucja Apostolska, nr 8.

$39 \quad \mathrm{KL}, \mathrm{nr} 84$. 
stopniowo w rozumienie i znaczenie - najpierw psalmów, a następnie poszczególnych godzin tej modlitwy.

Należy zaprezentować wiernym piękno śpiewu psalmów (rola przygotowania muzycznego). Zatroszczyć się, by śpiew oficjum stał na wysokim poziomie artystycznym i duchowym. Stosować krótki komentarz, objaśniający główną myśl psalmu ${ }^{40}$. Komentarz taki winien nie tyle ukazywać ścisłą egzegezę psalmu, ale raczej opierając się na wynikach egzegezy, pomóc modlić się danym psalmem, wprowadzić w temat uroczystości, świąt czy charakter danego okresu roku liturgicznego. Ze względu na duchowe dobro świeckich i umożliwienie im czynnego, świadomego uczestnictwa w modlitwie Kościoła - pozwala na pewne modyfikacje, a nawet improwizacje. Dotyczy to głównie np. doboru psalmów, czytań, a nawet całego formularza oficjum ${ }^{41}$.

Podczas przygotowania świeckich należy zwrócić uwagę, że tę formę modlitwy należy sprawować bez pośpiechu, w klimacie skupienia, godnie, z zachowaniem chwil świętego milczenia po czytaniu lub homilii. Liturgy Nie należy też zbytnio przedłużać. Powinno się uwzględniać konkretną sytuację danej wspólnoty (wieś, miasto, ludzie starsi).

\section{Etapy wprowadzania wiernych w Liturgię Godzin}

Po odpowiednim przygotowaniu wiernych w parafii czy wspólnocie, kapłan podejmie stopniowe wprowadzenie ich do udziału w Liturgii Godzin. Przykładowo na początku może przywrócić lub odnowić praktykę niedzielnych Nieszporów, zaprowadzić zwyczaj modlitewnego czuwania z rozważaniami przed Pasterką (Godzina Czytań), wspólnotowego sprawowania Liturgii Godzin w Triduum Sacrum, a następnie (po pewnym czasie) wprowadzić do codziennego udziału w Jutrzni i Nieszporach grupy liturgiczne czy apostolskie w parafii, by w końcu obdarzyć tą księgą modlitwy Kościoła rodziny, jak też pojedyncze osoby, szukające pogłębienia życia modlitewnego.

Nieszpory w Polsce miały swoją tradycję. Wprowadzenie wieczornej Mszy św. niedzielnej doprowadziło m.in. do ich wyrugowania z życia parafialnego.

$40 \quad$ Jest wiele nowych publikacji, zawierających komentarze Ojców Kościoła czy egzegetów - np. Psatterz grecki z komentarzami Świętych Ojców, Nauczycieli Kościoła i pisarzy bizantyjskich, przeł. H. Paprocki, Kraków 2017. 
Konstytucja o liturgii również porusza temat niedzielnych Nieszporów z udziałem wiernych ${ }^{42}$. Ogólne wprowadzenie także potwierdza to postanowienie Soboru ${ }^{43}$.

Wychowanie do udziału w Nieszporach trzeba zacząć od dzieci, młodzieży, grup liturgicznych, a więc poprzez katechizację i różnego rodzaju wychowawcze spotkania z ministrantami, służbą liturgiczną. Należy rozważyć problem nabożeństw okresowych, odprawianych zwłaszcza w niedzielę (np. majowych, czerwcowych, październikowych). Te nabożeństwa należałoby odprawiać w krótszej formie przed Nieszporami.

\section{Formacja do modlitwy - Liturgia Godzin w roku liturgicznym}

Konstytucja o liturgii i ogólne wprowadzenie, mówiąc o udziale świeckich w Liturgii Godzin ma na uwadze główne godziny dnia, a więc Nieszpory i Jutrznię. Dzisiaj istnieje realna szansa, by na początku w niektóre niedziele, np. Adwentu czy Wielkiego Postu, okresach szczególnego skupienia i modlitwy, śpiewać Jutrznię przed jedną z rannych Mszy św. przy współudziale scholi, ministrantów, lektorów i wiernych. Istnieje także możliwość łączenia tych godzin liturgicznych ze Mszą św.

\section{Liturgia Godzin w Triduum Sacrum}

Fundamentem formacji wiernych modlitwą Liturgii Godzin jest rok liturgiczny. Centralne miejsce tego cyklu kościelnego zajmuje Święte Triduum Paschalne przeżywane w parafiach. Są to najważniejsze dni w całym roku liturgicznym. Dlatego, posiadają niezmiernie bogatą liturgię, która wymaga gruntownego przygotowania przez właściwą katechezę, homilię i odpowiednie komentarze liturgiczne. Wielkie bogactwo tych dni powinno być przeżywane zarówno we wspólnocie parafialnej, jak i rodzinnej ${ }^{44}$.

W starożytności istniał zwyczaj wspólnego (z udziałem świeckich) sprawowania Liturgii Godzin. Śladem tego jest fakt, że wraz z zachowaną przez wieki bez większych zmian liturgią tych świętych dni, przetrwał zwyczaj śpiewania w kościołach tzw. ciemnej jutrzni przez duchownych i wiernych. Po Soborze Watykańskim II w liturgii Wielkiego Tygodnia ten zwyczaj uległ osłabnięciu. Jednak - poprzez język narodowy

\footnotetext{
$42 \quad \mathrm{KL}, \mathrm{nr} 100$.

43 OWLG, nr 207.

${ }_{44}$ T. Syczewski, Pastoralny wymiar roku liturgicznego, „Warszawskie Studia Teologiczne" XV (2002), s. 3.
} 
Liturgii Godzin - istnieje nowa szansa sprawowania jej przez duchowieństwo i wiernych z należytym zrozumieniem. Dobrze przygotowana liturgia Triduum Sacrum łącznie z modlitwą brewiarzową sprawowaną z wiernymi stanowić będzie „głęboką i wspaniałą katechezę Kościoła”.

\section{Godzina Czytań przed Pasterką}

O tej Godzinie Czytań odprawianej wspólnotowo mówi ogólne wprowadzenie, jak też dokumenty ostatnich polskich synodów. Zaleca się odpowiednie przygotowanie godziny czytań przed Pasterką, w celu wspólnotowego przeżycia uroczystej Mszy św. Bożego Narodzenia.

\section{Oficjum za zmarłych}

Nierozerwalnie z życiem parafii łączy się sprawowanie chrześcijańskiego pogrzebu, modlitwy za zmarłych, obchodzenie rocznic śmierci wiernych. Tę modlitwę za zmarłych można ubogacić i ożywić poprzez wspólnotowo sprawowaną Liturgię Godzin. Duże możliwości duszpasterskie dają odnowione obrzędy pogrzebu. W tym przypadku należy uwzględnić konkretne okoliczności parafii - inaczej można zrealizować ten program w mieście, gdzie pogrzeby odbywają się na komunalnych cmentarzach, inaczej na wsi, gdzie zazwyczaj istnieją cmentarze parafialne i czas pogrzebu ustala w zasadzie duszpasterz. Otóż tam, gdzie istniał zwyczaj śpiewania Jutrzni i Nieszporów żałobnych, należy go kontynuować i angażować w tę modlitwę całą wspólnotę. W innych miejscach można sprawować oficjum np. raz w miesiącu z okazji wspólnej Mszy św. za zmarłych; w listopadzie urządzać nabożeństwa z racji wypominków, odprawiać uroczyście Liturgię Godzin, np. żałobne Nieszpory, łącząc je z wymienianiem imion zmarłych, których wierni polecają modlitwie danej wspólnoty, czy to w ramach modlitwy powszechnej lub przed Nieszporami, zapowiadając niejako intencje tej wspólnej modlitwy.

\section{Liturgia Godzin w życiu społecznym, rodzinnym i osobistym}

Kościół pragnie, by odnowiona Liturgia Godzin stała się modlitwą, którą nie tylko celebruje się w kościele, z racji sprawowanej tam liturgii, ale by była podręcznikiem modlitwy w życiu codziennym, na zebraniach grup apostolskich, w rodzinie, a także by stanowiła osobisty modlitewnik każdego chrześcijanina ${ }^{45}$. Okazji do tych zebrań w parafii jest dużo.

$\overline{45 \quad \text { OWLG, nr } 27 .}$ 
Umiłowania modlitwy liturgicznej i posługiwania się w modlitwie psalmami należy uczyć już w domu rodzinnym, w kręgu najbliższych. Dzieci powinny zetknąć się z modlitwą psalmów ${ }^{46}$. Jest to impuls do dalszej odnowy liturgicznej, która ma dosięgnąć nie tylko zgromadzonych przed konkretnym ołtarzem wiernych, ale również i tych złączonych węzłami małżeństwa, rodziny.

Poszczególnym wiernym, którzy chcieliby, a nie mogą brać udziału we wspólnej celebrze Liturgii Godzin OWLG proponuje indywidualne odmawianie głównych jej części ${ }^{47}$.

Ciągła formacja liturgiczna (na wszystkich poziomach życia parafialnego) może sprawić, że parafie staną się wspólnotami ożywionymi - na wzór pierwszych gmin chrześcijańskich - duchem modlitwy, który przenikać będzie poszczególne rodziny i osoby. Gdy modlitwa liturgiczna staje się „,codzienną modlitwą Ludu Bożego”, codziennym pacierzem, przenikając do głębi modlitwę chrześcijańską, staje się skutecznym pokarmem duchowego życia Ludu Bożego.

\section{Liturgia Godzin w sanktuariach}

Sanktuaria - czy to diecezjalne, narodowe, czy międzynarodowe, są wspaniałym miejscem do modlitwy Liturgią Godzin. Sanktuarium może być szczególnym miejscem pomocy wiernym w odkrywaniu ducha tej modlitwy i włączenia ich w codzienne uwielbienie Boga przez Chrystusa w Duchu Świętym. Dlatego rektorzy sanktuariów powinni w programie pielgrzymek uwzględnić celebrację Liturgii Godzin, a zwłaszcza Jutrznię i Nieszpory ${ }^{48}$.

\section{Zakończenie}

Podsumowując omawiany temat, należy podkreślić, że odnowiona Liturgia Godzin przywraca całemu Ludowi Bożemu to, czym dla niego była modlitwa Kościoła w pierwszych wiekach chrześcijańskiej gorliwości. Liturgia horarium po Vaticanum II ma służyć wielkiej syntezie - akcji i kontemplacji, modlitwy i chrześcijańskiego życia. Istotnym rysem reformy liturgicznej na odcinku odnowy brewiarza

$\overline{46 \quad \text { Ibidem, } \mathrm{nr} 40 .}$

$47 \quad$ Ibidem, nr 18.

48 Congregazione per il Cultu Divino e la Disciplina dei Sacramenti, Direttorio su pietà popolare e liturgia. Principi e orientamenti (17.12.2001), Città del Vaticano: Libreria Editrice Vaticana 2002; tekst polski: Kongregacja ds. Kultu Bożego i Dyscypliny Sakramentów, Dyrektorium o pobożności ludowej i liturgii. Zasady i wskazania, Poznań 2003, nr 271. 
jest jej duszpasterski charakter. Człowiek zdaje sobie sprawę z tego, że jest zależny od Boga i przez modlitwę to wyraża. Księgą modlitwy jest Biblia. Dlatego też człowiek winien najpierw ją odkryć. Ona uczy nas, jak zwracać się do Boga. Lud Starego Testamentu był ludem modlitwy, modlił się trzy razy dziennie, modlił się psalmami. Modlitwę Izraela przejmuje Chrystus, a modlitwę Chrystusa przejmuje Kościól. Formacja zarówno osób zobowiązanych do Liturgii Godzin, jak i wszystkich chętnych jest bazą do świadomego i głębokiego przeżywania misterium liturgii uświęcenia czasu.

\section{FORMACJA KATOLIKÓW ŚWIECKICH DO MODLITWY LITURGIĄ GODZIN}

Liturgia Godzin według nauczania Kościoła jest modlitwą całego Ludu Bożego. Każdy bierze w niej udział, zgodnie z miejscem w Kościele: prezbiterzy, jak i wszyscy wierni świeccy - według możliwości. Modlitwa liturgiczna Kościoła może stać się zaczynem modlitwy osobistej, jeśli najpierw sami duszpasterze będą przekonani o jej doniosłości w życiu Kościoła, parafii i w życiu wewnętrznym poszczególnych świeckich. Konieczna jest odpowiednia formacja katolików świeckich w tym względzie. Również formacja seminaryjna w tym zakresie powinna kształcić wśród przyszłych kapłanów właściwe postawy. Bardzo ważne są obchody ku czci patronów metropolii, diecezji, parafii z połączeniem celebracji Liturgii Godzin (z włączeniem w nią ludzi świeckich). Rolę kluczową w recepcji tej modlitwy wśród świeckich odgrywa permanentna katecheza biblijno-liturgiczna. Jedną z dróg rozpowszechniania Ducha Liturgii Godzin jest przeżywanie tej formy modlitwy, jak i dojrzewanie do niej w małych grupach i stowarzyszeniach, które swoją praktyką „popularyzują” modlitwy psalmami.

Słowa kluczowe: Liturgia Godzin, modlitwa, celebracja, formacja, pieśń chwały, świeccy.

\section{Bibliografia:}

1. Pismo Święte Starego i Nowego Testamentu, Biblia Tysiaclecia, wyd. V, Poznań - Warszawa 2000.

2. Codex Iuris Canonici auctoritate Ioannis Pauli PP. II promulgatus (25.01.1983), AAS 75 (1983), pars II, s. 1-317; tekst polski: Kodeks Prawa Kanonicznego, przekład polski zatwierdzony przez Konferencję Episkopatu, Poznań 1984. 
3. Catechismus Catholicae Ecclesiae, Città del Vaticano 1994; tekst polski: Katechizm Kościoła Katolickiego, Poznań 1994.

4. Congregazione per il Cultu Divino e la Disciplina dei Sacramenti, Direttorio su pieta popolare e liturgia. Principi e orientamenti (17.12.2001), Città del Vaticano 2002; tekst polski: Kongregacja ds. Kultu Bożego i Dyscypliny Sakramentów, Dyrektorium o pobożności ludowej i liturgii. Zasady i wskazania, Poznań 2003.

5. Głowa W., Modlitwa liturgiczna. Liturgia Godzin, Przemyśl 1996.

6. Instrukcja o liturgicznej formacji w seminariach, Rzym 1979.

7. Ogólne wprowadzenie do Liturgii Godzin, Poznań 1992.

8. Paweł VI, Konstytucja Apostolska wprowadzająca w życie Liturgię Godzin uchwalona dekretem Drugiego Soboru Watykańskiego, [w:] Ogólne wprowadzenie do Liturgii Godzin, Poznań 1992, s. 12-18.

9. Sacrosanctum Concilium Oecumenicum Vaticanum II, Constitutio de Sacra liturgia Sacrosanctum Concilium (4.12.1963), AAS 56(1964), s. 97-134; tekst polski [w:] Sobór Watykański II. Konstytucje, Dekrety, Deklaracje. Tekst polski, Poznań 2002, s. 48-78.

10. Sacrosanctum Concilium Oecumenicum Vaticanum II, Constitutio de Lumen gentium; tekst polski [w:] Sobór Watykański II. Konstytucje, Dekrety, Deklaracje. Tekst polski, Poznań 2002, s. 104-166.

11. Sacrosanctum Concilium Oecumenicum Vaticanum II, Decreto de Apostolicam actuositatem, [w:] Sobór Watykański II. Konstytucje, Dekrety, Deklaracje. Tekst polski, Poznań 2002, s. 377-401.

12. Stowo Biskupów do kapłanów z okazji wprowadzenia Liturgii Godzin w języku polskim (1982), [w:] Dokumenty Duszpastersko-Liturgiczne Episkopatu Polski 1966-1993, oprac. Cz. Krakowiak, L. Adamowicz, Lublin 1994, s. 265-271.

13. I Synod Diecezji Drohiczyńskiej. Statuty. Dokumenty wykonawcze, red. A. Dzięga, M. Łaziuk, Drohiczyn 1997.

14. Syczewski T., Liturgiczna formacja alumnów $w$ wyższych seminariach duchownych w świetle dokumentów odnowy soborowej, „Studia Teologiczne - Białystok - Drohiczyn - Łomża” 10 (1992), s. 91-108.

15. Syczewski T., Pastoralny wymiar roku liturgicznego, „Warszawskie Studia Teologiczne" XV/2002, s. 187-198. 